\title{
CORRELATION BETWEEN THE PHYTOCHEMICAL CONSTITUENTS OF Curcuma mangga AND ITS IMMUNOMODULATORY EFFECT
}

\author{
Yuandani $^{1,2 *}$, S. Yuliasmi ${ }^{3}$, D. Satria ${ }^{4}$, R. F. Dongoran ${ }^{1}$, M. S. Sinaga ${ }^{1}$ \\ and N. H. A. Marpaung ${ }^{1}$ \\ ${ }^{1}$ Department of Pharmacology, Faculty of Pharmacy, Universitas Sumatera Utara, \\ Medan 20155, Indonesia \\ ${ }^{2}$ Centre of Excellence for Green Chitosan and Advanced Materials, Universitas Sumatera Utara, \\ Medan 20155, Indonesia \\ ${ }^{3}$ Department of Pharmaceutical Chemistry, Faculty of Pharmacy, Universitas Sumatera Utara, \\ Medan 20155, Indonesia \\ ${ }^{4}$ Department of Pharmaceutical Biology, Faculty of Pharmacy, Universitas Sumatera Utara, \\ Medan 20155, Indonesia \\ *E-mail: yuandani@usu.ac.id,yuan_dani@yahoo.com
}

ABSTRACT

The present study was conducted to correlate between the phytochemical constituents in the extract of $C$. mangga rhizomes and its immunomodulatory effect on phagocytosis of mice leukocytes. The phytochemical screening was performed using the standard method, while qualitative analysis of curcumin in $C$. mangga extract was examined using Thin Layer Chromatography (TLC). The $n$-hexane, ethyl acetate and ethanol extracts of C. mangga were introduced to carbon clearance method for their immunomodulatory potential. The phytochemical screening on $n$ hexane and ethanol extracts of $C$. mangga rhizomes revealed the presence of steroids and terpenoids. Meanwhile, glycosides, saponins and flavonoids were detected in ethyl acetate and ethanol extracts. The TLC analysis led to the identification of curcumin in all extracts. All the samples tested demonstrated the immunostimulatory effect on phagocytosis ability of mice leukocytes. Of all the extracts, $n$-hexane extract displayed the strongest stimulation on phagocytosis effect but there was no significantly different $(\mathrm{P}>0.05)$. The results suggest that the immunostimulatory activity of extract on phagocytosis ability was due to the presence of its major constituents although other constituents may also contribute.

Keywords: Curcuma mangga, immunomodulatory, phytochemical constituents, phagocytosis

๑ RASĀYAN. All rights reserved

\section{INTRODUCTION}

Nowadays, the utilization of medicinal plants to treat many diseases has increased ${ }^{1}$. The pharmacological activity of medicinal plants was contributed by its various active metabolite constituents. There are several secondary metabolites which have been reported to have important biological activities, which include flavonoids, saponins, glycosides, alkaloids, steroids, terpenoids, tannins and some other secondary metabolite ${ }^{2}$. These compounds were found to have various biological activities, such as antioxidant and immunomodulatory activities ${ }^{3-4}$. Immunomodulators are used for the treatment of many diseases due to immune system disfunction such as rheumatoid arthritis, lupus erythematosus dan immunodeficiency ${ }^{5}$. Immunomodulators might affect different lineages of the immune system. Phagocytosis in the main mechanism of the innate immune system to eradicate or eliminate invading organism ${ }^{6}$.

Rasayan J. Chem., 12(1), 1-6(2019)

http://dx.doi.org/10.31788/RJC.2019.1215050

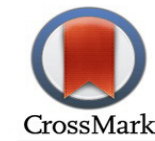


Phagocytosis which facilitated by recognizing bacterial structures directly or by recognizing opsonized bacteria is performed by pseudopodia to engulf an organism or particle, finally destroy the bacteria ${ }^{7}$. Several plants have been reported to have immunomodulatory effects such as Curcuma domestica, Curcuma xanthorrhiza, Gynura segetum and Andrographis paniculata ${ }^{4,8-9}$.

Curcuma mangga rhizome was found to be rich in various bioactive compounds. This plant has been used in traditional medicine to treat various diseases such as fever, stomach disorders and cancer ${ }^{10}$. The antiinflammatory, immunomodulatory, antifungal, anticancer and nitric oxide inhibitory activities of $C$. mangga have also been reported ${ }^{11-14}$. Safety assessment revealed that it was untoxic in show short-term treatment ${ }^{15}$. The previous study has also shown the immunomodulatory properties of C. mangga ${ }^{16}$. However, the correlation between phytochemical constituents and its immunomodulatory activity was seldom reported. The present study was conducted to examine the immunomodulatory effect of $n$-hexane, ethyl acetate and ethanol extracts of $C$. mangga rhizomes in an effort to correlate the activities with those of their constituents..

\section{EXPERIMENTAL}

The chemicals used in this study were natrium carboxylmethlcellulose (Na CMC) (Sigma, USA), nhexane, ethyl acetate, ethanol (SmartLab, Indonesia). Dragendorff reagent, Mayer reagent, Ferri (III) chloride, Molisch reagent, hydrochoride acid, sulfuric acid, Mg powder, amil alcohol, LiebermannBurchard reagent were obtained from Merck (Germany). Imboost ${ }^{\circledR}$ (Soho, Indonesia) as a positive control, $\mathrm{NaCl}$ (Otsuka, Indonesia), China ink (pelikan B-17) and acetic acid (SmartLab, Indonesia) were also used. Thin Layer Chromatography (TLC) plates were purchased from Merck (Darmstadt, Germany). A Spectrophotometer from Shimadzu (Japan) and a rotary evaporator from Heidolph (Germany) was used to perform the experiment.

\section{Plant Collection}

The C. mangga rhizomes were obtained from Sumatera Utara, Indonesia. Identification of plant was confirmed by a biologist in Herbarium Medanense (MEDA), University of Sumatera Utara, Indonesia.

\section{Extraction procedure}

The plant material was extracted by sequential maceration method using $n$-hexane, ethyl acetate and ethanol. Initially, the dried material (500 g of $C$. mangga rhizomes) was extracted with $n$-hexane. The extraction was repeated three times. Then, the residue was macerated with ethyl acetate, finally, the residue was macerated with ethanol. The solvent was removed using a rotary evaporator to obtain various extracts of $C$. mangga rhizomes.

\section{Phytochemical Screening}

The $n$-hexane, ethyl acetate and ethanol extracts of $C$. mangga rhizomes were investigated for the presence of flavonoids, alkaloids, steroids, terpenoids, tannins, saponins and glycosides. The color intensity or the precipitate formation after introduced with reagents were used as analytical responses to these tests.

\section{Test for Tannins}

An amount of $10 \mathrm{ml}$ of distilled water was added to the tube containing $0.5 \mathrm{~g}$ aqueous extract. Then, $2 \mathrm{ml}$ aliquot was added with 1-2 drops of $1 \%$ ferri (II) chloride. The dark blue or dark green color showed the presence of tannin ${ }^{17}$.

\section{Test for Saponins}

Ten (10) $\mathrm{ml}$ of hot distilled water was added to $0.5 \mathrm{~g}$ of extract in a test tube, the mixture was then cooled and it was mixed vigorously. The foam appearance with height around $1-10 \mathrm{~cm}$ for less than 10 minutes and disappeared after additional of 1 drop of $2 \mathrm{~N}$ hydrochoride acid showed the presence of saponins ${ }^{17}$.

\section{Tests for Flavonoids}

One hundred (100) $\mathrm{ml}$ of hot distilled water was mixed with $10 \mathrm{~g}$ of extract in a test tube and it was boiled and filtrated. Then, $5 \mathrm{ml}$ of filtrate was added with $0.1 \mathrm{~g} \mathrm{Mg}$ powder, $1 \mathrm{ml} \mathrm{HCl}$ and $2 \mathrm{ml}$ amyl alcohol. The yellow-red color in amyl alcohol layer showed the presence of flavonoids ${ }^{17}$. 


\title{
RASĀYAN J. Chem.
}

\author{
Vol. 12 | No. 1 |1 - 6| January - March | 2019
}

\section{Tests for Glycosides}

The aqueous extract $(3 \mathrm{~g})$ was mixed with $2 \mathrm{~N} \mathrm{H} 2 \mathrm{SO} 4(10 \mathrm{ml})$, refluxed for $1 \mathrm{~h}$, the mixture was then cooled and filtrated. Thereafter, $20 \mathrm{ml}$ filtrate was mixed with $25 \mathrm{~mL}$ distilled water, $25 \mathrm{~mL} \mathrm{~Pb}$ (II) acetate and it was filtrated. Then, $20 \mathrm{ml}$ filtrate was mixed with isopropanol and alcohol (2:3) and evaporated. The residue was dissolved in $2 \mathrm{~mL}$ methanol and added with $2 \mathrm{~mL}$ water and 5 drops of Molisch reagent. Finally, $2 \mathrm{~mL}$ of $\mathrm{H} 2 \mathrm{SO} 4$ was added carefully. A purple ring formed between the layers showed the presence of glycosides ${ }^{17}$.

\section{Test for Steroids and Terpenoids}

One (1) g extract was mixed with $20 \mathrm{~mL}$ ether, then it was filtrated and evaporated. The residue was added with the Lieberman-Bouchard reagent. A red color formed showed the presence of steroid, meanwhile, a purple or pink color showed the presence of terpenoids ${ }^{17}$.

\section{Tests for Alkaloids}

An amount of $0.5 \mathrm{~g}$ was mixed with $1 \mathrm{~mL} 2 \mathrm{~N} \mathrm{HCl}, 9 \mathrm{~mL}$ distilled water and it was boiled in a water bath, then cooled and filtrated. Then, 3 drops of filtrate with 2 drops of Mayer reagent or Bouchardat reagent or Draggendroff reagent. The precipitate formation at least after additional two above reagents showed the presence of alkaloids ${ }^{17}$.

\section{Qualitative Analysis of Curcuminoids using Thin Layer Chromatography (TLC)}

The determination of curcuminoid in three different extracts ( $n$-hexane, ethyl acetate and ethanol extracts) was conducted using Thin Layer Chromatography method as described previously by Stahl $(1995)^{18}$. Each extract was spotted in TLC silica gel and eluted with chloroform: benzene: ethanol $(45: 45: 10)$. Then, it was observed under various wavelength of UV lamp (254 and $366 \mathrm{~nm})$. It was also sprayed with vanillin-sulfuric acid to confirm the presence of curcuminoids.

\section{Phagocytosis Response}

The phagocytosis response was investigated according to our previous study ${ }^{19}$. Briefly, mice were treated with $n$-hexane, ethyl acetate and ethanol extracts of $C$. mangga at doses of $100,200,400 \mathrm{mg} / \mathrm{kg} \mathrm{BW}$ for 7 days. The vehicle only (Na CMC 0.5\%) was administered to mice in the negative control group. Imboost ${ }^{\circledR}$ $(32.5 \mathrm{mg} / \mathrm{kg} \mathrm{BW}$ ) was used as positive control. Then, all the animals were injected through the intravenous route by China ink dispersion $(0.1 \mathrm{ml}$ per $10 \mathrm{~g})$. Thereafter, the blood samples were collected at an interval of 5, 10, 15 and $20 \mathrm{~min}$ and added to $1 \%$ acetic acid. Finally, the level of carbon in blood was measured as absorbance value using spectrophotometer at $640.5 \mathrm{~nm}$. The livers and spleens were removed after $12 \mathrm{~h}$ of blood collection.

The rate of carbon clearance $(K)$, phagocytic index $(\alpha)$ and stimulation index were calculated by using the following formula:

The rate of carbon clearance $(\mathrm{K})=\frac{\log \text { OD5 }-\log \text { OD20 }}{\mathrm{t}_{2}-\mathrm{t}_{1}}$

Phagocytic index $(\alpha)=\frac{\mathrm{K}^{1 / 3} \mathrm{x} \text { body wt of animal }}{\text { Liver } \mathrm{wt}+\text { spleen } \mathrm{wt}}$

Where OD5 is the log absorbance of blood at $5 \mathrm{~min}$; OD20 is log absorbance of blood at $20 \mathrm{~min}$; $\mathrm{t}_{2}$ is the end time point of blood collection; $t_{1}$ is the initial time point of blood collection. The study was approved by the Animal Research Ethics Committees of the University of Sumatera Utara (approval number 0289/KEPH-FMIPA/2018).

\section{Statistical Analysis}

The data were analyzed using SPSS version 15.0. A one-way analysis of variance (ANOVA) and followed by the Tukey post hoc test with $\mathrm{P}<0.05$ were calculated to determine the significance of the difference. 


\section{RASĀYAN J. Chem.}

Vol. 12 | No. 1 |1 - 6| January - March | 2019

\section{Phytochemical Screening}

\section{RESULTS AND DISCUSSION}

Table-1 shows the phytochemical constituents in the various extract of $C$. mangga rhizomes. Three different solvents were used to prepare the extract, which includes $n$-hexane, ethyl acetate and ethanol in order to investigate the chemical constituents extracted by the different polarity of the solvent. The results are expressed as (+) for the presence and (-) for the absence of phytochemicals as shown in Table-1. The phytochemical screening of $n$-hexane extract demonstrated the presence of steroids and terpenoids. Flavonoids, saponin, and glycosides were detected in ethyl acetate and ethanol extracts of C. mangga. In addition, steroids and terpenoids were also detected in ethanol extract. This result might be due to the incomplete extraction by $n$-hexane or high amount of steroid/terpenoids in $C$. mangga rhizomes. However, all those compounds are widely known to have biological activity. Terpenoids are reported to enhance the immune system $^{20}$. In aggreement with our previous study which reported the immunomodulatory activity of $C$. mangga rhizomes $^{19}$.

Table-1: Secondary metabolites in the extract of C. mangga rhizomes

\begin{tabular}{c|c|c|c|c}
\hline \multirow{2}{*}{ No. } & Secondary metabolites & $n$-Hexane extract & Ethyl acetate extract & $\begin{array}{c}\text { Ethanol } \\
\text { extract }\end{array}$ \\
\cline { 3 - 5 } & & & - & + \\
\hline 1. & Flavonoids & - & - & + \\
\hline 2. & Alkaloids & - & + & + \\
\hline 3. & Saponins & - & - & - \\
\hline 4. & Tannins & - & + & + \\
\hline 5. & Glicosides & + & - & + \\
\hline 6. & Steroids/terpenoids & \multicolumn{2}{l}{} \\
\hline
\end{tabular}

\section{Qualitative Analysis of Curcuminoids using TLC}

Our previous study reported that crude ethanol extract of $C$. mangga rhizomes contains curcuminoids (curcumin, demethoxycurcumin and bisdesmethoxycurcumin) ${ }^{21}$. The present study was conducted to evaluate the distribution of curcuminoid in the various extract obtained using different polarity of the solvent. Curcumin in curcuminoids was eluted with $\mathrm{Rf}$ value of 0.66 , meanwhile, in $n$-hexane, ethyl acetate and ethanol extracts were $0.63,0.63$ and 0.66, respectively (Fig.-1). Determination of demethoxycurcumin in the extract was confirmed by the presence of spot in $\mathrm{Rf}$ value of $0.57 \mathrm{in} n$-hexane and ethyl acetate extract and 0.58 in ethanol extract which was comparable with $\mathrm{Rf}$ value of demethoxycurcumin in curcuminoids standards (Rf: 0.57). Meanwhile, the presence of bisdemethoxycurcumin (Rf value: 0.51 ) was confirmed by Rf value of 0.50 and 0.51 in ethyl acetate and ethanol, respectively.

The results indicate $n$-hexane extract contained less amount of curcumin and demethoxycurcumin, while bisdemethoxycurcumin was not detected in this extract which showed by the less color of the TLC spot. Meanwhile, ethyl acetate and ethanol extracts contained a significant amount of curcuminoids. Curcuminoids are polyphenolic compounds thus, might be extracted by semipolar and polar solvent ${ }^{22}$. The result was in agreement with phytochemical screening which showed the presence of flavonoids and another semi polar and polar compounds.

\section{Phagocytosis Response}

The effect of $n$-hexane, ethyl acetate and ethanol extracts on phagocytosis response was determined by carbon clearance method. The high difference of absorbance between the initial and end time point of blood collection indicates the high clearance rate of carbon particle due to carbon engulfment by mice leukocytes. All the samples tested at various doses $(100,200$, and $400 \mathrm{mg} / \mathrm{kg})$ showed higher phagocytic index than the negative control $(\mathrm{P}<0.05)$, signifying that they were enhancing the immune response (Fig.2 ). The $n$-hexane extract of $C$. mangga demonstrated the strongest stimulant but still comparable with others extracts of $C$. mangga $(\mathrm{P}>0.05)$. However, the stimulatory activity of n-hexane extract of $C$. 
RASĀYAN J. Chem.

Vol. 12 | No. 1 |1 - 6| January - March | 2019

mangga with phagocytic index of ranging from 2.03- 2.28 was much lower than positive control, Imboost $^{\circledR}$ with a phagocytic index of 6.82 and crude ethanol extract of $C$ mangga as reported in our previous study with a phagocytic index of $6.71^{19}$. The enhancement of phagocytosis activity of $n$-hexane extract might be due to the presence of terpenoids and curcuminoids. The previous study reported that terpenoids could enhance the intracellular killing effect of macrophages ${ }^{20}$.

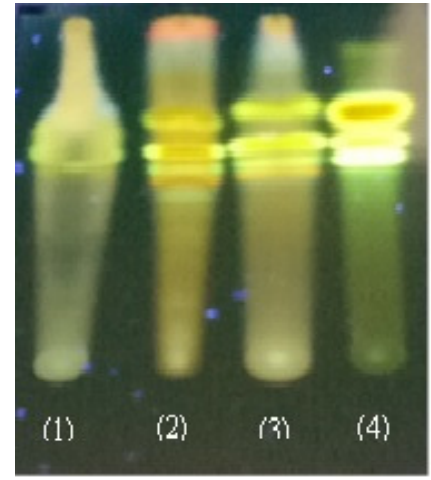

(A)

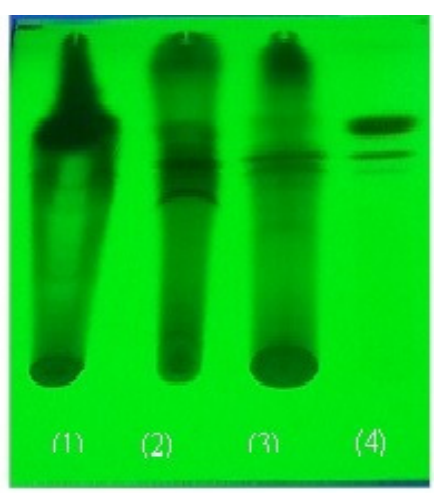

(B)

Fig.-1: Curcuminoid analysis (Curcumin: Rf 0.66, Demethoxycurcumin: Rf 0.57, Bisdemethoxycurcumin: Rf: 0.51) (A) Observation under UV lamp $254 \mathrm{~nm}$; (B) Observation under UV lamp $366 \mathrm{~nm}$; (1) $n$-hexane extract of $C$. mangga (2) ethyl acetate extract of $C$. mangga (3) ethanol extract of $C$. mangga (4) Curcuminoid standard

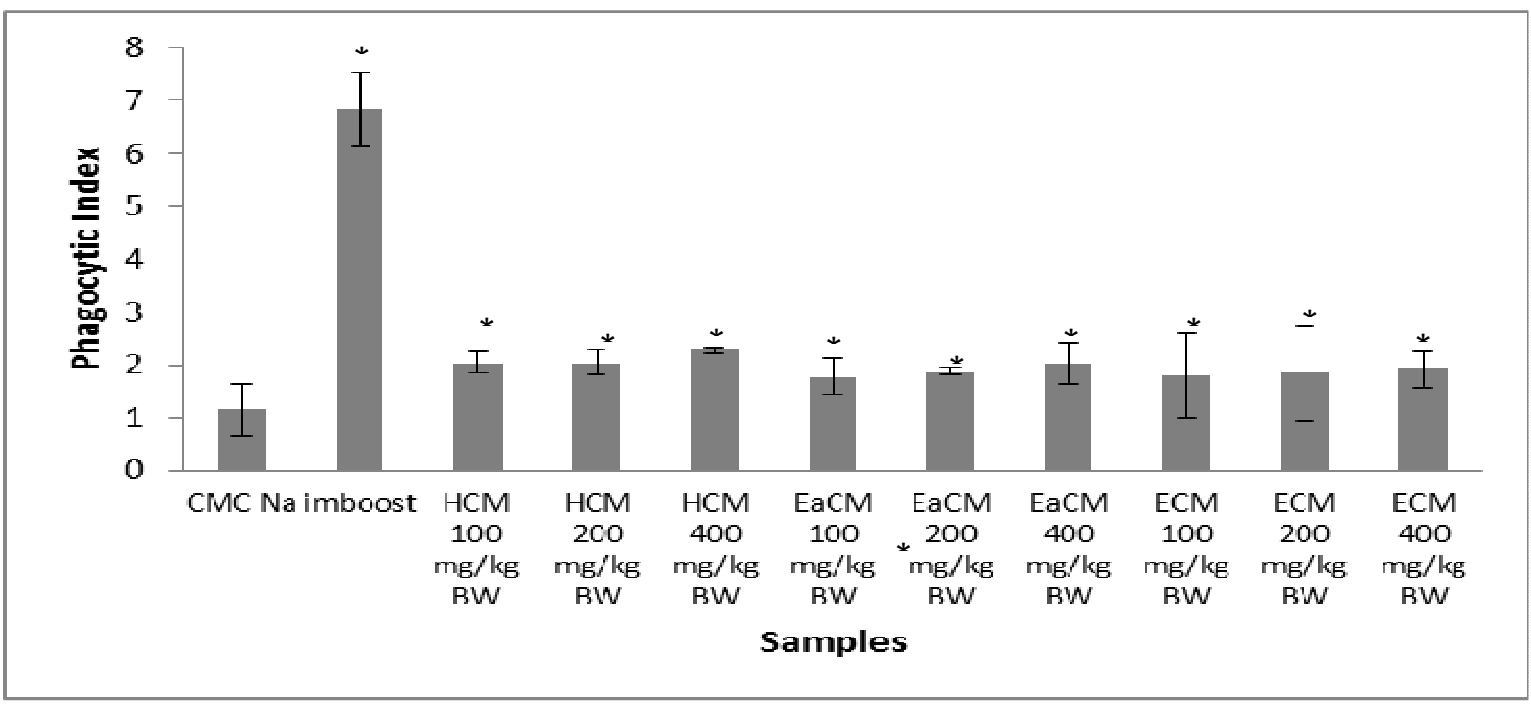

Fig.- 2: Effect of C. mangga extracts on phagocytosis ability of mice leukocytes; (HCM) $n$-hexane extract of $C$. mangga; (EaCM) Ethyl acetate extract of C. mangga; (ECM) Ethanol extract of C. mangga; Data are mean $\pm \mathrm{SEM}, \mathrm{n}=5, * \mathrm{P}<0.05$ significant with respective control

However, the immunomodulatory activity of those three extracts was not significantly different, indicating that most constituents play role in stimulating phagocytosis response. In addition, our previous study reported that crude ethanol extract of $C$. mangga demonstrated much stronger stimulation in phagocytosis ability of mice leukocytes ${ }^{19}$, signifying that interaction of all active constituents play a major contribution in enhancing the immune response.

\section{CONCLUSION}

The phytochemical screening led to the identification of steroid/terpenoids in $n$-hexane and ethanol extracts of C. mangga rhizomes. Meanwhile, flavonoids, glycosides and tannins were detected in ethyl 
RASĀYAN J. Chem.

Vol. 12 | No. 1 |1 - 6| January - March | 2019

acetate and ethanol extracts. Further investigation on curcuminoid content in various extracts revealed the presence of low amount of curcuminoids (without bisdemethoxycurcumin) in $n$-hexane extract and high amount of curcuminoids in ethyl acetate and ethanol extract. All the extracts of Curcuma mangga were able to increase phagocytosis ability of mice leukocytes. The $n$-hexane extract showed the highest phagocytic index but still comparable with other extracts, signifying the immunostimulatory effects of all the extracts were similar to each other. Hence, from the results obtained, it can be concluded that most constituents in Curcuma mangga play role in immunomodulatory effects. However, further investigations are necessary to elucidate the components in C. mangga and their activity on other mechanisms of immunomodulatory responses.

\section{ACKNOWLEDGMENT}

This study was supported by Universitas Sumatera Utara, through scheme grant TALENTA with contract number of 2590/UN5.1.R/PPM/2018.

\section{REFERENCES}

1. S.D. Roy, S. Das, D. Shil, K.N. and Dutaa, World J. Pharm. Res., 1, 87 (2012).

2. Y. Cai, Q. Luo, M. Sun and H. Corke, Life Sci., 74, 2157 (2004), DOI: 10.1016/j.lfs.2003.09.047.

3. E. Iqbal, K.A. Salim and L.B. Lim, Journal of King Saud Univ.-Sci., 27, 224 (2015), DOI: 10.1016/j.jksus.2015.02.003.

4. Yuandani, J. Ibrahim and H. Khairana, BMC Complement Altern Med. 17, 211(2017), DOI: 10.1186/s12906-017-1726-z.

5. U.S. Patil, A.V. Jaydeokar and D.D. Bandawane, Int. J. Pharm. Pharm. Sci., 4, 30 (2012).

6. S.D. Kobayashi, J.M. Voyich, C. Burlak and F.R. DeLeo, Arch. Immunol. Ther. Exp. (Warsz) 53, 505 (2005).

7. A. Filias, G.L. Theodorou, S. Mouzopoulou, A.A. Varvarigou, S. Mantagos and M. Karakantza, BMC Pediatr., 11, article 29(2011), DOI: 10.1186/1471-2431-11-29.

8. I Jantan, H.N. Hikmah, S.A. Wira, S. Murad and M.A. Mesaik. J. Nat. Med., 65, 400 (2011).

9. R.A. Kumar, K. Sridevi, N.V. Kumar, S. Nanduri and S. Rajagopal, J. Ethnopharmacol., 92, 291 (2004).

10. L.F. Abas, D.A. Khozirah, N.H. Israf, S. Jhonson and Y.U. Kalsom, J. Nat. Prod.. 68, 1090 (2005), DOI: $10.1021 / \mathrm{np} 0500171$.

11. P. Ruangsang, S. Tewtrakul and W. Reanmongkol, J. Nat. Med., 64, 36(2010), DOI: 10.1007/s11418-009-0365-1.

12. A.H. Karsono, O.M. Tandrasasmita and R.R. Tjandrawinata, Cancer Manag. Res., 6, 267 (2014), DOI: $10.2147 / \mathrm{CMAR}$.

13. L.F. Abas, N.H. Israf, D.A. Khozirah and Y.U. Kalsom, Food Chem., 95, 566 (2006).

14. I. Jantan, M.A.M. Yassin, C.B. Chin, L.L. Chen and N.L. Sim, Pharm. Biol., 41(5), 392 (2003), DOI: org/10.1076/phbi.41.5.392.15941.

15. Yuandani and E. Suwarso ${ }^{a}$, Asian J. Pharm. Clin. Res., 10, 383 (2017), DOI: 10.22159/ajpcr.2017.v10i1.16196.

16. Yuandani, S. Yuliasmi and D. Satria, Rasayan J. Chem., 11, 844 (2018), DOI: 10.31788/RJC.2018.1122097.

17. J.B. Harborne, Phenolic compounds. In Phytochemical methods. Springer Dordrecht pp. 37-99 (1984).

18. E. Stahl, Drug Analysis by Chromatography and Microssopy translated by Kosasih Padmawinata ITB Bandung pp. 3-18 (1985).

19. Yuandani and E. Suwarso ${ }^{\mathrm{b}}$, Asian J. Pharm. Clin. Res., 10, 148-50 (2017), DOI: 10.22159/ajpcr.2017.v10i9.18398.

20. P. Venkatalakshmi, V. Vadivel and P. Brindha, Int. J. Green Pharm., 10, 1 (2016).

21. Yuandani and S. Yuliasmi, Asian J. Pharm. Clin. Res., 11,129 (2018), DOI:10.22159/ajpcr.2018.v11s1.26586.

22. W. Wichitnithad, N. Jongaroonngamsang, S. Pummangura and P. Rojsitthisak, Phytochem. Anal., 20, 314 (2009), DOI: 10.1002/pca.1129.

[RJC-5050/2018] 